\title{
EXPERIMENTAL STUDY ON ALLERGIC OTITIS MEDIA
}

\author{
(Part 1: Allergenic effect of Proteus Vulgaris on guinea \\ pigs sentitized with egg albumin.)
}

\section{By}

Rokuro SEKI

\section{From the Department of Otolaryngology School of Medicine, Juntendo University Director: Professor Ishikura}

The author carried out an experiment on allergy affecting hearing organ of guinea pigs to study the relationship between allergy and chronic otitis media.

A solvtion containing proteus vulgaris was injected into the bulla of the middle ear of 24 normal animals which had been previously sensitized with egg albumin.

The animals were divided into 8 groups of 3 animals each, and were sacrificed at intervals of 4 hours, $1 \sim, 3 \sim, 5 \sim, 7 \sim, 10 \sim, 15 \sim$, and 30 days for histo-pathological examination of the bulla and and the labyrinth.

In the 4-hour -and 1-day-specimens, there were accumulation of secretion and falling of cilia out of the ciliary epithelium; there were remarkable edema, bleeding, and eosinophiles (the so-called allergic findings) in the submucous tissue.

The 3-day-specimens showed less edema, bleeding, and eosinophiles; however, proliferation of connective tissue and inflitration of round cells (the so-called infectious findings) were found.

In the 5 , $7 \sim$, and 10-day-specimens, there were signs of remarkable inflammation and osteogenesis in the submucous tissue.

In the $15 \sim$ and 30-day-specimens, the ciliary epithelium returned to normal, and the inflammatory process was subsided in the submucous tissue.

Dilalation of the stria vascularis was noticed in the labyrinth all specimens of 4 -hour, $1 \sim, 3 \sim$, $5 \sim, 7 \sim, 10-$ day.

During the course of 15 and 30 days, a tendency of healing to the normal state was detectable.

Each cell was mildly swollen in the organ of Corti. In some cases there were swelling or looseness of Reissner's membrance, most of which, however, showed a normal histology.

In the $3 \sim, 5 \sim, 7 \sim, 10$-day speciemns, a secretion of fibrinoid substance was noticed in the scala vestibuli. 


\title{
アレルギー性中耳炎に関する実験的研究
}

\author{
第 1 編 Proteus Vulgaris のアレルギー効果
}

（即白アルブミンにて感作した場合）

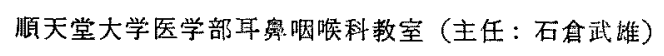

闒六郎

目次

第 1 章 緒言

第 2 章 害験材料

第3章 実験方法

a）感作方法（アレルギー惹起法）

b) 稩菌感染法

c) 病理組絿磷本作製

\section{第 4 章 実験結果}

第】群（PV 注入後 4 時間経過したもの）

第】群（PV 注入後24時間䋊過したもの）

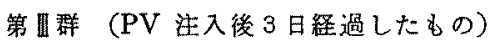

第 $N$ 群（PV 注入後 5 日経過したるの）

第り群（PV 泩入後7日経過したもの）

第 V群 (PV 注入後10日経過したるの)

第训群（PV 注入後15日経過したむの）

第记群 (PV 注入後30日経過しはもの)

第 5 章 実験成縤小括

第6 章 文塥考案

第 7 章 考察及び総括

第 8 章 結語

\section{第 1 章 緒言}

慢性中耳炎を治療する際抗生洞の投与に依り直口治

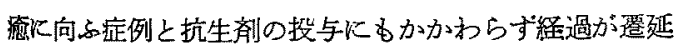
する症例儿㕍々遮遇する，加る際に抗七スタミン剂を 併用することに依り治癒に向占場合がある，即ち慢性中 耳炎は㫿単に紐菌感染のみでなくアレルギーが橍与して いるすのがあることを推察することがでさる，近時アレ ルギーの実験的硚究も一投と盛えとなり，その本質につ いてる次第に解明されてきたとは云え末だ末解泱の点が 多く聴器フレルギーに関する研究について子病理組織学 的所見に関しては未だ明らかでない面もある。著者は鳃 器アレルギーに関する動物些験を行ない病理組織学的所
見について考察を試みたのでこれに報告する。

\section{第 2 章 実験材料}

a) 動 物

実験材料として一般に感受性に富さ動物として最むよ く使用される海猽を用ひ臸膜所見正常，ブライェル氏反 応鋭敏な体重 $350 \mathrm{gr}$ 前後のるのを使用した。これら海

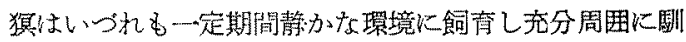
化した後に春験に供した。

b) 抗 原

抗原として卵白の生理的食壏水溶液を使用した，即ち 大江の方法により卵白を眀黄より分けて 2 枚のガーゼに

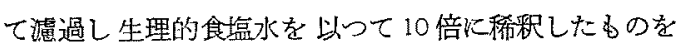
使用の度每に作製した。

c) 変形菌 (Protess Vulgaris 以下 PV と略記) 変形菌の梌出方法は澡野 D方法飞徒ひ慢性化澧性 中耳炎患者の分泌物より，患者の外耳道をピロゾンにて 形の如く清拭したのち可及的に鼓室内の分泌物を隇菌綿 棒で採取し，その未ま，普通寒天培地及び血液寒天培地

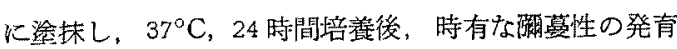
を示すものを更に0.2\%の石宸酸普通寒天平板培地及び $\mathrm{S}, \mathrm{S}$ 培㦈地に叙坤培盖し，それそれから独立した集落 を拾つて分離培善し，更にウレアーゼ産生の有無，その 他を検查して変形菌（PV) としての性状を確かるた。 分離後の变形菌 (PV) の菌株は $0.5 \%$ の半流動寒天培 地に穿刺培着し $0^{\circ} \mathrm{C}$ の水室に保存し以下の実歌に供し た，培荃した糸形菌 (PV) を $2 \sim 4 \mathrm{mg} / \mathrm{cc}$ の生菌浮游 即ち，10ccに対して一白金耳の割合で作り使用の度毎 に作製使用した。

\section{第3章 実験方法}

a）感作方法 (アレルギー巷起法)

予め上記の方法で作製した $10 \%$ 卵白液を動物体重每 然 $1.0 \mathrm{cc}$ を海猉の腹壁皮下に 1 回注射した後，更に 2 週 
後 $10 \%$ 卵白溶液を腹胵队注射して全身感作を施した。

b ) 細菌感染法

上記方法により卵白フレルギーにて感作した海猉に生 菌浮游液 $0.2 \mathrm{cc}$ をエーデル麻酥のもとに尖端を鈍にし た針をるつて左側中耳骨胞内汥膜を明視しつつ経鼓膜 的に注入右側聴器は対照とし比較㓋察した。

c) 病理組織標本作製

病理組織標本作製の目的で上記方法で感作及び細菌感 染を行つた海猽を下記の各期間を経過した後それでれエ 一テル麻酔施行の下に開胸し，必臓及び上行大動脈を充 分に露出したのち下行動脈を結染，カニューレを大動脈

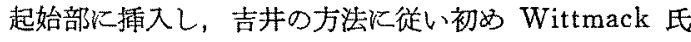
液にて生体固定を行い断頭後 5 日間 10\%ホルマリン液 にて固定の後イオン交热樹脂 $10 \mathrm{gr}$ にて $10 \%$ 蟙酸 $80 \mathrm{cc}$ を重畳した液で約 2 週間脱灰 $5 \%$ 酼酸ナメリウム液にて 中和水流, 脱水の順序にて行つた. 包埋はパラフイン包 埋法を用い 6 8 8 の連続切片を作製，染色住主として ヘマトキシリンエオシンン重染色を行つた。

\section{第 4 章 実験 結 果}

予め感作した海猽に变形菌 (PV) を中耳骨胞に注入 した後そ机それ 3 頭づつ4時間，24時，3日5日7日 10日15日30日各絽過の8群炕分けこの8群に就いて 生体固定を行ない型の如く，前記方法に上り病理組織学 的観察を行つた，各群におりる笑験成續は次の如し．

第 I群 (PV 注入後 4 時間経過したもの

No. 82 , No. 86 , No. 87)

実験動物 No. 87

生体固定;

心臓の活動はやゃ不良で墨汁注入までに停止し生体固 定は不成功であつた．左側中耳骨胞を開放するに腔内に は凝血が認められ分选物の貯溜を認める，鼓室粘模は軽 度に肥厚する。

組織学的所見;

線毛上皮の部位においては上皮細胞は分泌六進を示 し，所々に腺体の空胞化を示す，線毛は一部に存在する が大部分に括いて脱落し消失する、又上皮の娳離が所办 に認められる。

粘膜下組織においては出血栄が所々飞認められ墨汁の 血管内への注入像が所々に認められる. 結合組織の增殖 はほとんど認められなかつたが浮遁が中等度に認められ る. 円形細胞が散見しその中に好酸球を証明できる、リ

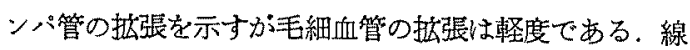
稚莱細胞及び骨芽細胞は出現せず骨組穖の異常は認めら
れない，屚平上皮の部位においてて所見は線毛上皮の部 位の所見とほぼ同様であるが浮遁はやや軽度である。羫 内には分泌物が楒められ，Hammer の周囲の粘膜も軽 度肥厚し，線毛上皮の部位と同様な所見を呈す，又好酸 球が証明できる。特に Hammer の周囲には分必物が多 量比認められる。

対 照 側;

線毛上皮はやや分泌克進するも，線毛は大部分に存在 する，粘膜下組織に和いては出血策は認められず，唯赤 血球が散在する，浮㖤怯軽度で旦つ硝子様化を呈す，粘 膜は蹯鬆状を呈す。

内耳組織;

血管帯に和ける血管の拨張は軖度で，上皮細胞質内に 空胞は認められないコルチ氏器に括いては各細胞は軽 度膨化し，各細胞間牦軽度に線維素様物質の折出が認め られ，各細胞境界は明瞭である。内外毛細胞は形がくら

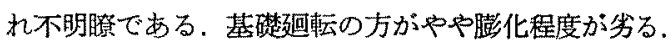
上方迥転の前庭階に㓙く軽度であるが，細胞の浮游を認 める。ライスネル氏膜は軽度の膨隆を示す。

\section{対 照 側;}

血管带に和ける血管は軽度に拉張し、コルチ氏器に括 ける各細胞は膨化し，前庭階には異常は認められない。 ライスネル氏膜は軽度膨隆するが全体として注入側より 所見はやや少る。

第【群（PV 注入後24時間経過したあの No. 83 , No. 84 , No. 85 )

動物番号 No. 83;

Wittmack 氏液使用，生体固定は成功与る，胞内 は㠜血至認め，中耳粘膜は軽度肥厚し，分汹物の賩溜を 認める。

組織学的所見:

線毛上皮の部位に和いては，上皮細胞は分泌六追し， 所に上り空胞化を呈し，線毛上皮は所なに剝離が認めら れ，排列はややみだれている．線毛は大部分において脱 落し消失する．粘瞙下組織仁执いては出血巣が所々に認 められ結合組織计軽度肥厚し，浮䐦は中等度である，円 形細胞は極少数認められ，その中に好酸球を証明でき る。一部上皮直下に就いては高度の浮脾を呈す、リンパ 管の抎㖘を示すが，毛細血管の㹡張はほとんど認められ ない，線維芽細胞及び骨芽細胞の出現はなく，骨組織の 異常は認められない，扁平上皮の部位儿おいては線毛上 皮の部位に批ける所見々同様である。中耳腔内忹整度 の膿性分泌物が認められ，同時に赤血球を混した線維素 
样物質の折出を呈す，赤血球の間に好酸球を証明する。 Hammer の周囲の粘膜は肥厚し，出血单を呈し，との 附近には澧及び線維素物質の折出が多い。

対 照 㑡;

線毛上皮の部位においては上皮細胞山軽度の分速元准 を示し，線毛は大部分化存在する，粘膜下組織において は出血巣，浮遁及び円形細胞はほとんど認められす文好 酸球の出現もみられないが一部には蹯影状を呈し，硝子 化孛示す所もある。

内耳組織;

血管带に批りる血管は㹡張し，所々に上皮細胞質内 に空胞を示す。 コルチ氏器においては，ダイテル氏、へ ンゼン氏各細胞は同等に膨化するがクラヂラス氏細胞は 前者よりやや劣る、各細胞間の境界はやや不鮮明で細胞

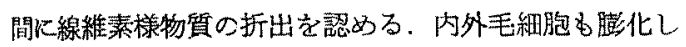
境界怯不鮮明であり，旦つ原形はくづれている。ライス ネル氏摸は上方廻転で膨隆を示すが，他は正常状態を示 す，上方迴転において前庭階に線維様物質の折出を認め ろ.

対 照 側;

注入側の所見と比較しやや軽度であるが同様な所見を 呈す，前庭階汇円形細胞の游出は認められない。

第团群 (PV 注入後 3 日経過したもの No. 58 , No. 59 , No. 60)

動物番号 No. 58 ;

生体固定;

Wittmaack 氏液を使用，生体固定は成功する、中耳 粘膜は肥厚し，分淡物は認められず，対照側はほぼ正 常.

組緎学的所見;

線毛上皮の部位に批いては，上皮細胞の分泌立進が軽 度に認められ，軽度の膨化像を示寸，線毛上皮の剝離が 所により認められるが，線毛上皮の排列はほぼ正常，線 毛は大部分に残存する，粘膜下組織に怙いては所々に赤 血球が散見し，結合組織の增殖が出現し，浮祭は中等度 に認められる。円形細胞浸潤は俥度に認められ，その中 に好酸球を証明する。リンパ管の㹡張は著明であるが， 毛細血管の拉張は著明ではない，

線維芶細胞が所々に出現するも，骨茅細胞の出現は認 められず，骨組織比は異常は認められない，扁平上皮の 部位に朔いては，ほ湶毛上皮の部位と同様であるがや 中出血像が強く旦つ毛細血管の脑張が強い，
対 照 側;

線毛上皮の部位は上皮細胞が軽度に分泌元進し，所に より空胞を示す．線毛灶大部分に执いて存在する。粘膜 下組織に括いては軽度の浮通が認められ，硝子化を呈 す。粘膜下組織は疎鬆状を示す。

内耳組織;

血管帯に猢ける血管は著明に㹡張し，所々に上皮細胞 間に空胞を示す。コルチ氏器における各細胞は著明に膨 化し，各細胞間の境界は基礎迴転ではやや不明膫である が上方迴転に括いては境界は明膫である。な膨化は基 礎迴転で上方迴転に比しやや劣る。ライスネル氏膜洼ぼ 正常であり，前庭階には少数の円形細胞を認める。

対 照 側;

血管帯に持ける血管は拨張し、コルチ氏器の各細胞は 全䢙転火おいて膨化するが，注入側に比較してやや劣 る.紐胞間の境界は明瞭で他には異常を認めない，

第N群 (PV 注入後 5 日綵過したもの No. 168 , No. 169, No.170)

動物番号 No. 168 ;

生体固定;

Wittmaack 氏液使用，生体固定成功する。中耳粘膜 は高度に肥厚し，軽度の分汹物を認める。

組織学的所見;

外耳道近接部位に括いては，線毛上皮の扁平化が認め られ，線毛上皮の豩離は認められず，線毛は大部分に打 いて脱落し消失する。線毛上皮細胞間飞円形細胞浸潤が 認められ，空胞は铝められず。粘膜下組織においては， 少数の赤血球が散見されるが，著明な出血栄刃は出血点 は認められない，結合組織の增加が強く，浮聥は極く軽 度に認められる。リンパ球を主体とした円形細胞浸潤が 認められるが，その中には好酸球は証明できない，毛細 血管の㹡張が著明なるに比較し、リンパ管の㹡張はやや 劣る、線維芽細胞が認女られ，また骨周辺飞沿つて骨芽 紐胞が認められる。しかし骨組織には異常を認めない。 扁平上皮の部位においては，扁平上皮直下に円形細胞浸 潤が著明で且つ充血及び浮臄も著明であり、リンパ管の 拨張も喼められる，特に骨周辺に沿って骨泺細胞が出現 し，旦つ骨新生像を示す．中耳腔内には好中球を主体と した䁸性分泌物が認められるが，線維素物質の折出は認 められない。

対 照 側;

前群即ち 3 日経過したものとほぼ同様の所見を呈す。 
内耳組織；

血管带に括ける血管は軽度の抎張を示す，出血及び充 血は䜑められない、コルチ氏器の緗胞中ダイテル氏， へ ンゼン氏各細胞は同程度の膨化を示すが，クラヂウス氏 細胞は洞者よりやや劣る。各細胞間の境界は明瞭であ り，整度の線維素性物質の折出を各細胞間仁認める。 イスネル氏膜は晞度の弛緩を示す，前庭階にはライスネ 儿氏膜に沿つて線維素性物質が珰められる。

対 照 側;

血管帯にお汗る血管は軽度の脑張を示す。コルチ氏器 の各細胞は膨化を示すも注入側に比較し少る。シイスネ ル氏膜及び前庭陆には異常は認められない。

第V群 (PV 注入後7日緋過したもの No.171, No.172, No.173)

動物番号 No.171;

生体固定;

Wittmaack 氏液使用，生体固定成功寸る，中耳粘膜 の肥厚を呈し，分泌物の眝溜を諗める。

組織学的所見;

線毛上皮の部位に拁いては，耳管開口部要で線毛上皮 の排列は2焒れず，所々に線毛上皮の列離が認められ る. 外耳道近接部においては，粘膜表面に膿性分注物が 密着し，粘膜の一部は肉莪を形成する．他の部位の粘膜 上皮は上皮細胞間に多核白血球の浸潤が認奶られる。粘 膜下組織に括いては，結合組織の墙殖が著明で，出拀， 浮腯はほとんど認められず。円形細胞浸が強いが，好酸 球は証明できない，毛細血管の摭張が認められ，線毛上 皮值下には，リンバ管が哆開しており，これ《沿つて硝 子様物質が認以られる，粘膜上皮下の結合織以は線維芽 細胞加認められ，骨新生像を示す，扁平上皮の一部に和 いては強い円形細胞浸潤を認め，結合組織が認められ る。即ち肉䒬の発生を示す。扁平上皮の 部位において 6，線毛上皮の部位々同㥞線維芽細胞の出現，骨新生像 をみる，中耳骨胞内には，膘性の分泌物が多量浔認めら れる。線毛上皮の部位では，粘膜下組織に著明な円形竐 胞浸潤を認めるが，扇平上皮の部位に版いては硝子様化 され，円形細胞浸休あまり認められない。

対 照 側;

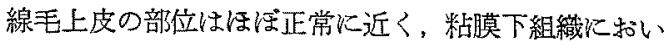

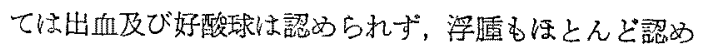

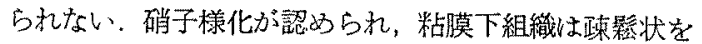
是する。
内耳組織;

血管帯に和いては，血管がやや著明飞拢張し，上皮細 胞質閆は軽度の空胞を示す。コルチ氏器においては，ダ イテル氏細胞，ヘンゼン氏細胞の膨化仿同程度にみら れ，クラヂウス氏細胞は両者よりやや劣る。な郝膨化は 全迴転汇和いて認められ，各細胞間の境界はやや不鮮明 である，シイスネル氏膜はほぼ正常，上方迴転ではライ スネル氏朕に沿つて，線維索性物質認認める。

対 照 側;

血管带に打ける血管の拡張，コルチ氏器各細胞の膨化 とも認められるが，注入側に比較して劣る，各細胞の境 界は明膫である。ライスネル氏膜は正常，前庭階，鼓室 階之も異常を認めない。

第V群（PV の注入後10日経過したもの

No.61, No.62, No.68, No.69)

動物番号 No.61;

生体固定;

Wittmaack 氏液を使用，生体固定は成切する。中耳 粘膜は中等度に 肥厚し，凝血及び 分泌物の 貯溜を認め る.

組織学的所見;

線毛上皮の部位に郝いては，上皮細胞間に円形細胞浸 潤唯認められ，線毛上皮の排列はみだれて約らず，線毛 上皮の剝離俚認められないが，線毛は大部分に和いて脱 落し消失する，粘膜下組織に打いては，粘膜上皮直下に は中等度の円形綀胞浸潤が認められるが好酸球は証明で きない，結合組織の 增殖が著明で 軽度の浮豦が認めら れ，毛細血管の㹡張を示し，リンパ管の多開を認める. 線維苇細胞が比較的著明比認められ，骨周辺に沿つて，

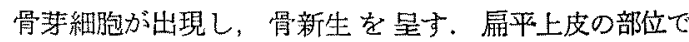
は肉芳の発生を認め，一部軽度のリンパ管の师開を示 し，所々に円形細胞浸潤が】つの塊りとして認められ る. 線維莱緗胞の出現が強く骨周辺に沿つて骨军細胞が 認められ，骨新生を示す，又硝子様性物質を認める，骨 胞内には膿性分泌物が認められる。

対 照 側;

線毛上皮に括いては上皮細胞の軽度分泌充進を認める が排列は正常，楾毛は大部分に执いて存在し粘膜下組織 に打いては円形細胞浸潤ははとんど認められず，硝子様 性物質を認める，粘膜下組織は眯鬆状を呈する。

内耳組織;

椇管带における血管は㹡張し、コルチ氏器に乱けるダ イアル氏，ヘンゼン氏各細胞は同程度に膨化し，クシヂ 
ウス氏緗胞は両者よりやや胖化が少る，各細胞間の境界

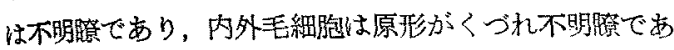

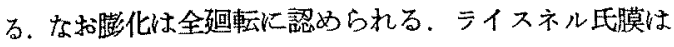
軽度の幗隆を示す．前庭階には異常は認められない。

対 照 侧;

血管帯に肪ける血管の拡張, コルチ氏器の各細胞の膨 化を呈するが注入側の所見と此較して出る，前庭倩には 異常を绫めない。

第田群（PV 注入後 15 日緃過したもの No. 63, No.70, No.71, No.72)

動物番号 No.63;

生体固定;

Wittmaack 氏液を使用する，生体固定は成切する。 中耳粘膜は軽度肥厚し，分泌物は認められず。

組織学的所見;

線毛上皮はほぼ原形に復するが，一部においてい上皮 細胞間に円形細胞浸淍が認められる，線毛上皮の剝離は 認められず線毛は大部分に存在する。粘膜下組織に扣い

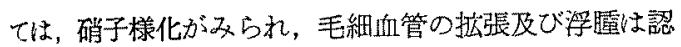
められない，又円形細胞は認められない，一部において

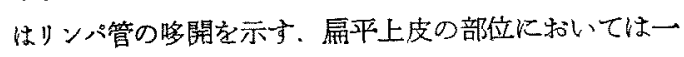
部肉茅を星すが，一般に硝子様化は線毛上皮に比較して 著明である。

対 照 側;

血管带における血管の脑張，上皮細胞質内の空胞化， コルチ氏器の各細胞の膨化は前群とほ注同様でするが,

特別な所見は認められない。

内耳組織;

血管带に和ける血管は軽度の㹡張を示し，上皮細胞犋

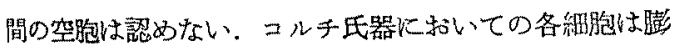
化を示し，細胞間の境界は明瞭であり，各細胞間汇軽度 の線維素物質を折出する。ライスネル氏膜は驻に゚正常で ある。

対 照 側;

血管带に和ける血管の拉張, コルチ氏器各細胞の膨化 の所見を圼するが，これらの所見は注入側と同様であ ๖.

第训群 (PV 注入後 30 日経過したもの No. 76 , No. 77 , No. 81 )

動物番号 No. 76;

生体固定;

Wittmaack 氏変を使用する。生体固定は成切する。 中耳粘膜は軽度の肥厚を認めるが，分汹物の貯溜は認め
られない。

絽轿学的所罗;

線毛上皮は注驻正常に復し，線毛は大部分に存在す る. 粘膜下組織においては，円形細胞は少く，浮唒は消 失し、リンパ管及び毛細血管の菭張山認められない，線

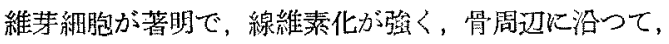

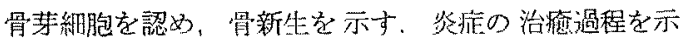
t.

対 眼 側;

線毛上皮は忹ぼ正常に復し，粘朝下䋎織は線維化が強

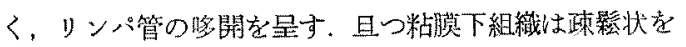
旺す。

内耳組織;

血管帯に执ける血管の拡張し上皮細胞筫間には空胞 は認められない，コルチ氏器に和ける各細胞とす膨化 し，上方迴転に和いてはダイテル氏，ヘンゼン氏各細胞 は同程度に膨化するが，クラヂウス氏細胞は雨者よりや

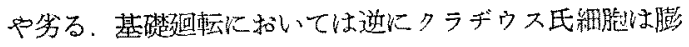
化はやや著鹏である，基礎逐転に和いては細胞間の境界 は不明，上方而転に和いては，各細胞間の境界は朋膫で ある。ライスネル氏膜ははぼ正常，前庭階，鼓室階とも 異常は諸められない。

詨 照 側;

\section{注入側とほぼ同様な所見を呈する。}

\section{第 5 章 実験成樍小括}

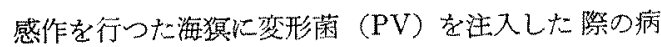
理組織学的所見を時間的綴過に從つて観察すると，先つ 中耳粘膜に就いては，変形菌 (PV) 注入後 4 時間，24時 間，3日の比較的早期䌯過に和いては，いつれも線毛上 皮細胞は分速它進し，所々に腺細胞の空胞形成がみられ る。線毛上皮は所ヶ剝離し，鳎状学呈与る。線毛の状熊 は脱落し消失寸る例方多く，線毛上皮の排列は添ぼ正常 であるが，No.64k执いては，線毛上皮の排列はみだ れ，上皮細胞間に円形細胞漫潤を認線毛は大部分顺落

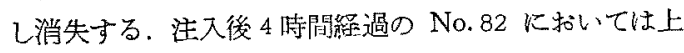
皮細胞間江酸球を認める。次に5日䌊過与ると粘膜上 皮は一部で扇平化を示し，一部《抋いては，上皮細跑間 に多核白血球の浸潤老呈し，線毛以脱落し消失寸るもの が多い，7日経過するに粘膜上皮の所見は5日猛過時に 括けるとほぼ同様で方るが，上皮細胞間に多核白血球の 浸潤がやや強くなり，战膜表面䐬性分泌物が密接し， 粘膜の一部では肉茅の形成もある。10日䌊過において は粘膜上皮細胞間に多核白向球の浸潤を示し，一部では 


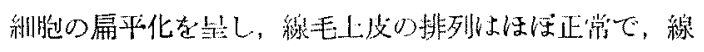
毛は大多数に执いて脱落し消失する，15 日絴過すれば 一部上皮細胞間琏圣度の多核白血球浸潤を認めるが，他 の上皮の部分で江次第に原形に復し旦つ線毛は大部分存 在する.30日に到机ば粘膜上皮は完全に原形に復し線 毛る完全に存在する. 右耳即ち 対照側の粘膜上皮を比 較観察してみると，4時間，24時間，3日の絽過時に和 いては腺上皮細胞性分泌充進し，所に上り空胞を示す が，注入側に 比較してその程度は著明でない，6日， 7 日経過に朔いては一部の例では上皮細胞の分泌充進を 呈すが，大部分の例ではほぼ正常に近い，10日䋊過で も同様な所見字呈し，15日，30日に到れば粘膜上皮は ほぼ原形に復す。線毛の脱落消失及び線毛上皮の㓦離に よる柾状所見は全縂過にわたつて認められなかつた。

次に粘膜下絹織の变化沉就いて述べてみると，変形菌 (PV) 注入後 4 時間蜀過においては著明な出血栄が認め られ，小円形細慥の散見を示し，一視野 4〜5の割合で 好酸球を証明できる、結合組織の增殖はなく，浮延が中 等度に認められ、リンパ管の拡張を示すが，毛細血管の 抎張は認められない，24時間绍過炕括ける所見は，ほ ぼ 4 時問経過時の所見之同様であるが，浮䐘はやや著明 となつている. 対照側の所見は出血巣は認められず赤血 球が散見し，浮堙が軽度に認められ硝子様化を呈し，粘 膜下絽䢂は政影状を呈す。 24 時間緼過ではほぼ 4 時間 経過における所見と同様である．３日絽過すると出血巣 はま代認められるが 4 時間，24時間路過に比較すると やゃ劣り No. 60 では赤血球の散見のみである，これに 反し円形細胞の出現をみ，旦つ次第に結合絽織の堌殖を

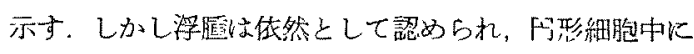
は一視野 1〜2 個程度の好酸球を証明でさる。リンパ管 の脑張を認めると同時炕毛細血管の搪張る所に上り見ら れる上らになつてくる，次ぎに5 日経過すると出血の状 態さ，出血巣怡次第に少くなくなり，赤血球の散見を示 す程度である、次第に円形細胞浸潤が著明となり，結合

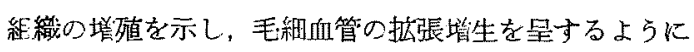
なつてくる、しかし今迄著明な浮框を示していたが，漸 次減弱し，一部においては活と九ど認められぬようにな つて来，好酸球は完全に消失し証明できない，この時期 に到ると今迄出現しなからた線維芽細胞の出現が認めら れ，旦つ骨周辺には軽度でわあるが骨芽細胞も認められ るようになつてくる。７日絽過時期に括ける粘膜下組織

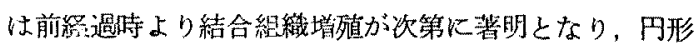
細胞浸潤も同様に強くなり，旦つ毛細血管の增生，掞張

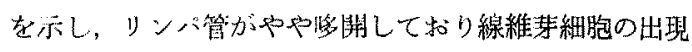

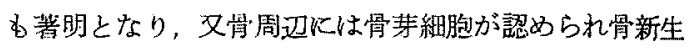
がこの時期に初めて認められるようになつてくる。扁平 上皮の部分で法硝子様変生し一部では肉芽の発生をみ， 骨苯縕胞及び盈新生が線毛上皮の部位よりやや著明に認 められる，10日縚過すると粘膜上皮の一部は扁平化を 呈し，粘膜上皮直下にびまん性に丹形細胞が認められ，

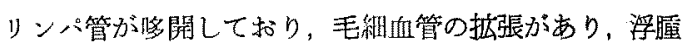
は軽度に䛑められる。線䊒芽細胞の出現が強く扁平上皮 の部位においては，硝子様変性を示し，骨周迅に沿つて 骨芽細胞がやや著朋汇認められ，骨新生像を呈す，又文 の一部には肉芽が発生し, 各所見は線毛上皮の部分より

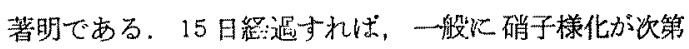
に強くなり，毛紐血管の拉張好淿とんど認められず，浮

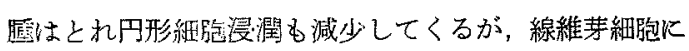
依然著明で骨莱細胞及び骨新生も認められる。肁平上皮

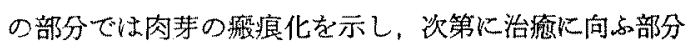

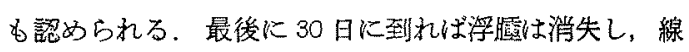
維莱細胞が強く炎症の治癒過程を示す. 次いて中耳腔に 打ける分泌物の貯溜状態山夜形 (PV) 菌注入後 4 時間, 24 時間の早期においては，中耳腔には線維素性物質の 折出, 赤血球, 円形細脂特飞好中球を認めその中に混在 して好酸球を証明できる。それ以後の絘過時においては 好酸球は認められず，主に化膿性の分议物であり，15

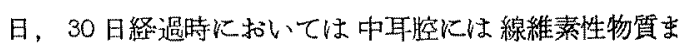
たは化膿性分必物は認められなるつた。

次に内耳絽織特住血管帯，コルチ氏器，ライスネル氏 膜及び前庭階鼓室階の状態飞就いて述べてみる，血管帯 の㹡张は大部分に認めら机る。注入後 4 時間絽過の早期 飞和いては，㹡張は比較的軽噔であり，7日及び10日 独過すれば著朋となつてき，15 日及び30日に到れば搪 張は再び軽度となる．細胞の空胞化は 4 㭙間縔過では軽 度であるが，24 時閒以上䋗過では大部分比認められる。

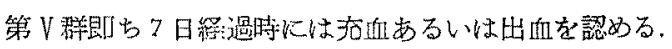
次いてュルチ氏器に捺ける各細胞は注入後 4 時間絽過に おいてのみ軽度の膨化を示すが，他の総ての群の例飞お。 いては中等度の膨化が認められ，第【群つ No. 83，第N 群の No.168, No.170, 第 V群 No.171, 第 V群 No.61, No. 69 と和いてはダイテル氏，へンビン氏各細胞は同 程度に膨化を示すが，クラヂウス氏細胞の变化は前 2 者 上りやや劣る所見を星する。第四群 No. 58 は各备転沉 物いてクラヂウス氏，ヘンゼン氏，ダイテル氏各細盷 とも著明な膨化を示す，第VII No.70 む同様に著明に旦 


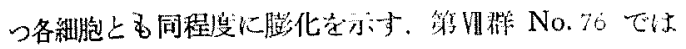

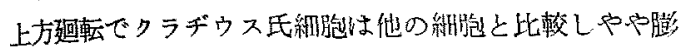

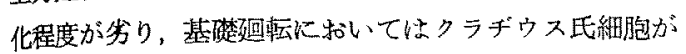
他の各細胞と比較し膨化が著明である．次いて各絧胞間

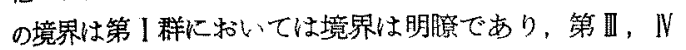
群 No. 59, 第 N 群, 第训群も同栐纪境界は明嘹である。

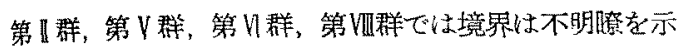

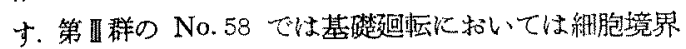
はやや不朋瞭であるが，上方迴転では明瞭である。ライ スネル氏膜の状態に就いてい，第 I 群即ち栾形菌注入後 4 時閏経過時のもの及び第 III，第 V，第VI，第训群では 正常状熊を示し，第 I群，第り群では軽度の膨隆状態を 示寸が，第四群に和ける No.64，第N群に的ける No. 169, 第 V群の No. 172，は軽度な䟝緩を示す.

最後に前庭階に打污楾稚素性物質の折出，队形細胞 の游出あるい、赤血球の游出の諸状態沉就いては第 I 群 №.87 にのみ上方廻転に極く軽度の円形細肹の游出を 認める。第 $\mathbb{I}$ ，第 $\mathbb{I}$ ，第 $\mathbb{N}$ ，第 $V$ ，第 $V$ 群の全例におい て線維素性物筫の折出か，あるいは円形細胞の游出が認 められる。

第叫，第四群の例に执いて異常は認められないが，た 民゙ No.71 と赫いてのみ，ライスネル氏膜に沿つて赤血 球の折出を認める。

次ぎに対照側に亮いては，第 I群では血管带における 血管の挔張及び全迴転においてコルチ氏器の各細胞の膨 化及びライスネル氏膜の膨隆等を認めるが，前庭階には

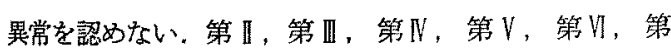

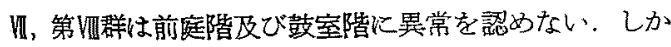
し他の所見は注入側と比較し軽度でわあるがほぼ同棣な 所見を呈している。

\section{第 6 章 文献考察}

アレルギーなる言葉は1906年 Pirquet 2)が変つた区 応と云う意味で始めて用いた。，即ち抗原抗体に起因寸 る生体反応から過敏と免度とを総括する概念としてア レルギーなる言藮を提唱した，動物に暴種蛋白体を注射 し一定の日数趶過後, 更に該動物に同一なる蛋白体を雨 び注射することに伡り，その動物に特異なる過敏性「シ シック」をきたすが， Riechet ${ }^{3)}$ はこれを過敏症と呼ん 犬゙. Rössle 4)は再び注射を皮下又は組織に施ゼば全身 症状を䓗起せずしてその局所以著明な炎症性変化を起す ことを認め是を「ヒペルエル非ー」性变化と命名した。 又 1903 年 Arthus ${ }^{5)}$ 汇做り Arthus 現象として，馬血 清を反覆注射することにより，その局所飞头症を起し，

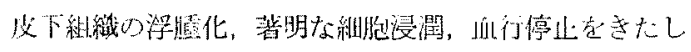
強度でするものは局所に㙼死形成まで発現することを認

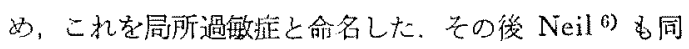
様な事寒を認め、こ机苍所謂「アレルギー」と称するに 至つた，その後局所「アレルギー」が重要な研究題目と なり，多数の学者により研究され，又各歲器において局

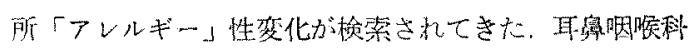

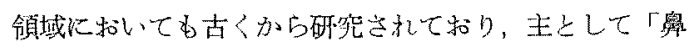
フレルギー」に関しては本邦においても多数の研究が発 表されてきた。しかし聴器「アレルギー」に関倸する契 験的研究は割合に少くなからた。

その後アレルギーの定義は三田7，Rössll，Urbach

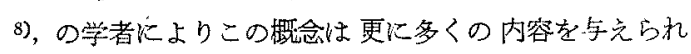
よるうになつてきた。緒方 ${ }^{9}$ 《抗原抗体反応が生体に 皮仿す作用のらち病的の過程を示すものをつレルギーと 云い武田 ${ }^{10)}$ 《抗体に上り抗原が処理される過程の様々 の現象であると云うように説明している，以上の如く 「アレルギー」は内外の学都によつて定義され，旦つ解 釉されてきたが現在な招不明な点が多い上うに考へられ る.

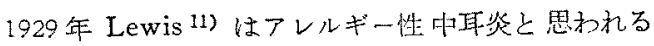
36 例を報告し，その6 例中 3 例が 笑管支揣息を持ち 3 例がフレルギー性番梹患を訴党ていると述べ全身アレル ギーがアレルギー中耳资に深い関係を持つていると結論 附けている. 次いて Proetz ${ }^{12)}$ が 1931 年に食铒性フレ ルギーを原因とした急性中耳炎の10例を，次いて1938 年にJones ${ }^{13)}$ が同しく食郋性アレルギーを原图とした アレルギー性中耳炎の1例報告している。衫膜所見は 輸状部々㨢骨柄に沿う軽度の発赤を示すのみでは蒼白

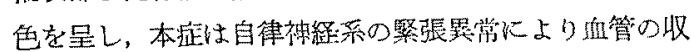
緶及び㹡張作用の障碍が中耳粘膜に発赤をきたしたるの

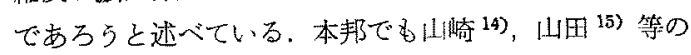
臨床報告がある。.Hansel ${ }^{16)}$ はモルモット馬血清，牛乳 で感作しこれ等の感作動物の中耳腔に馬但清，牛乳を注

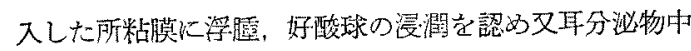
に好酸球の增加を見この变化住牛乳よりも馬血清の方が

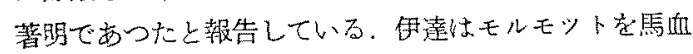

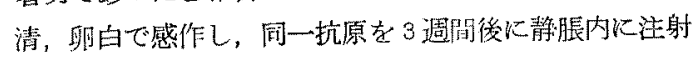
して強いSchock を起して死几だものと10日閒生存せ しめたものを比較䋩察した結果ンシッ多したものの中 耳及び内耳には多量の漫出液, 虑出液, 出血コル千氏器 に著しい変化を認めたが Schock を起さなかつたすの に扣いては病変は軽度中耳腔归には㴰出液を認めたと報 
告している，Koch ${ }^{17)}$ 愔牛乳及び 馬血清にて 動物を感 作した場合の組織学的所見を報告した，中耳挖に多量の 分泌物の貯溜をみ，その中に好酸球を証明したと述べて いる. 又粘呫にも出血，浮腿及び円形練胞浸潤を示し， 又好酸球を粘膜下組織に拉いて証明できたと述べ牛乳の 感作よりも馬血清にて感作した場合の力が諸所見が著明 に出現すると記载している。伊達 ${ }^{18)}$ 《聴器の「アレル ギー」性変化をDoerr の「アナフラキシー」学説に則 り研究したもので琹らく本邦に捯ける該实験的研究の最 初のものと思わ机る。固城 ${ }^{19)}$ 《前処置群, 非処固群, 感作群の三群に分けて抗原は馬血清を用い，動物実験を 行つた，前処置群に执いては聴器ではなん等の変化を認 めず，非処置群に打いては軽度の粘膜の変化が諸めら れ，注入後 96 跱間後に打いて消裉する。感作群に括け る聴器の変化岋著明で，早期より著明なる「アレルギ 一」性变化を認めたと述べている，香宗我部 200は低温 の聼器アレルギーに及淩す影響に就いての实験的研㠰を 行ない，固城と同様に分け，前処置は馬血清を注射した わの感作群は馬血清で感作後同一抗原を注入したもの で，前処置群では殆んど变化はなかつたが，非感作群に

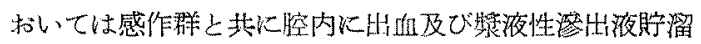
が認められた，挖内粘膜は「アレルギー性」变化を示し たと報告している。

Derlacki ${ }^{21}$ ( (外耳，中耳，内耳のアレルギ一性疾患 の症例について報告し、中耳では中心性第孔有する慢

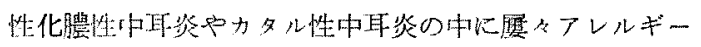
性のものがあり，百にアレルギー性と思わ机る内耳障碍 の 2 例を報告し，門らかな慢性中耳炎の 262 例の中 52 例は分䎵物の中に好酸球を持ち，そしてアレルギー中耳 炎の証㚭を瞕示させたと述べている，六島2:日) はカタル

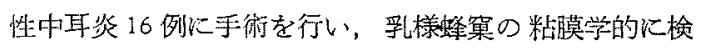
乙, 強い㳂出現象粘膜と結合組織の膨化, 毛細血管の拡 張及び透過性の充進，好酸球の游走等の所見から本症発 現の因子として等総的な中耳腔陰王と共にフレルギー性 反応を考へる事ができると述べている，Palva 293 は乳 様突起炎に拉けるアレルギーの变化に就いて急性, 亜 急性，慢性の乳様突起炎で手術を行つて得られた標本は 71 例耳で，この手術耳に括ける好酸球の存在に就いて

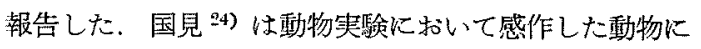
細菌を注入した場合を比較して述べているが，組織像に

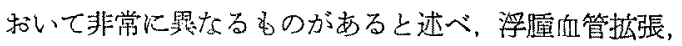
好酸球浸潤，出血巣の発現等が認められるが，これに反 し円形細胞浸溜は比較的軽度であると報告している. 伸
村25)は結核アレルギーと聴力との関係に就いて次ぎの 如く述べている. 即ち結核アレルギーの立場から考へて みると，初回注射群では初接種後 I 週間比して B.C.G. を抗原として抗体が生じこれに抗原，抗体反応が生れ る. 更にアレルギー反応がすすんで個体のアレルギー化 の最も強い3週間後に括いては高低音とも30\% 60\% の低下を認めるが，いづれる高音障碍が高度である. 再 注射群では再注射後は更に低下し初回注射 7 週後では高 音にて約 60\% 低音にて約 40\% の低下を多いてる. 重複 注射群では 6 週後にて高音にて約 30\%，低音にて約 20 $\%$ の低下を示亓と報告している，又仲村は病理組織に 訧いて発表しているが， B.C.G.の1回注射に和ける二 ルチ氏器細胞及び血管带の脜大が認められ，再射におい てはコルチ氏器細胞及び血管带の遮大は著明となると述 ベている. Meerhoff 26)は結核感染に格ける内耳の組織 的変化に就いて結核アレルギーを強調し，内耳組織の变 化が著明で，特に血管带及びュル千氏器各細胞の膨化像 を示し，境界は不朋膫となり，旦つ細胞間炕線維素性物 質の折出を熹めると，又時には前庭階，鼓室階飞滲出液 の折出を証明できると報告している，和田 ${ }^{27)}$ は馬血清

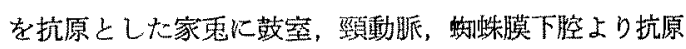
を注入，豉室迷路のアレルギー性病变とみなされるべき 所見を得，組織学的所見は鼓室粘膜の出血，水腰性缰 脹, 血管脑張及び血管周困の白血球浸潤, 線維蒜物質の

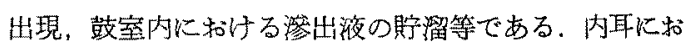

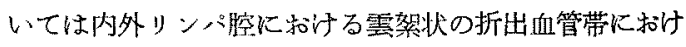
る血管扰張，細咆浸潤を認めたと報告している，豊田28) はアレルギー様区沁を伴つた中耳炎の4例即ち外耳湿 疹，耳溜中の好酸球の增多を示した2例，中耳炎手術創

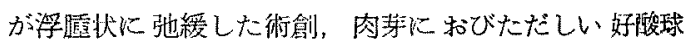
游出を認め，病理緦絊の梌穼により「アレルギー」性 変化を思放せる所見をみい出した．Friedmann ${ }^{29}$ は鼓 膜発赤なく，浮蕾状穿孔中耳粘膜同様 分泌物中少数の Diplokokken と母視野1 2 ケの好酸球を認め, 抗上ス

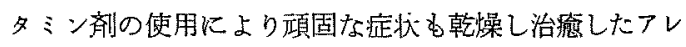
ルギー性变化を伴つた中耳炎の1例を報告した，白川3n! は全身感作動物に鼓室上り抗原を注入する場合には䖮牛 前莛に法出物が現われ，病变は実駼動物に一様に起るも のではなく時には極めて軽度であり時にはかなり強く登 現すると述べている，倉井 ${ }^{31)}$ は聴器迷路のアレルギー 反応を観察するため，家鬼にアルチュス及びシュロルッ マン型組織反応营起させ，この際追跡法を応用して各 抗原に金属互鉛を Träcer として添加した，以後臨床 
的観察と共に迷路縁織内の亜鉛検出を反応の実熊とその 部位的関保を追究し，次の如く一方に批いては迷路絽織

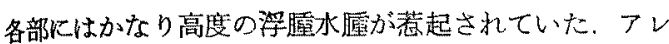
ルギー反応を示す亜鉛橙色顆粒は緝織病変にほぼー致し 明膫に検出されたが，その位置的時間的関倸から血管寡

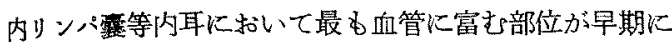
強い反応を起寸ことが証明された。 日比野 ${ }^{32}$ )は㯖器了 レルギー時に淤ける血管带繥䋘呼吸は，組織学的変化は 並行して低下あるい譜加するすのであり，機能的変化 そ組蟣学的変化と添结並行していると考光られる。本杉

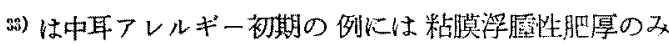

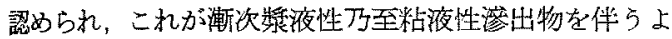
らになる，中耳フレルギー例では極めて早期に於いての みアレルギー性病变の特長を示し，その後は急速に病変

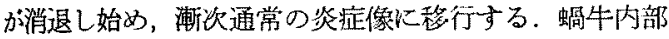
には中耳フレルギー例では逆に，線維素物質が多数汇網 状をなして出現した。

コルチ氏器䌈胞は膨化し各細胞間の境界は不明賩であ

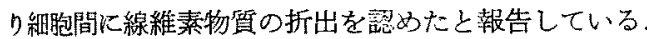
樎間 24) 性局所フレルギー区沁による内耳病態関して

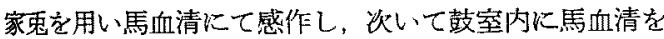
注入した．その結果，中耳粘膜に抢いては浮遥膨化を示 し，中耳腔は多量の出血並びに好酸球の出現を呈したと 述へ，又内耳に执いては，血管帯は搪張し空胞を示し， ライスネル氏膜は挙上し，コルチ氏器の各細胞は膨化 し，前庭階汉べクラ少量折出し，少量の出血を認めた と述べている。

以上の各動物実駼は 1903 年 Arthus の馬血清による

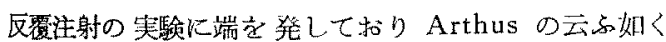
局所の炎症を起し皮下組織の浮㯖膨化と著明なる細胞浱 潤，血行停止をきたし，又好酸球の出現，強度なるもの 岋局所に罗死形成まで発現を認める。これらは縕織学的 所見から観察したるのである。

\section{第 7 章 考察及び総括}

アレルギー反応が線毛上皮にいかなる変化を示すかと 云う問題はアレルギー性中耳炎を解明するに必要な政恼 であり，それ故考察を述へる前に正常海猽に拈ける中耳 战莫の状態就いて検討を加党ることわアレルギー反応 の際の組織学的所見を論ずる場合に必要な事である。 Koch ${ }^{35)}$ の論方飞打いて子正常海慎化和ける中耳粘膜 の状態を熟知寸ることは，動物実験を行ふ際に必要なこ とであると記載している，正常海㩧における中耳粘膜の

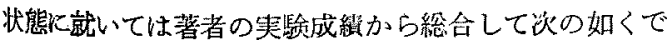

ある、幼若海猉に打いては中耳粘膜は比较的厚く被覆上

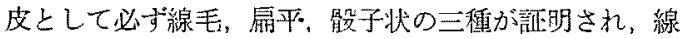
毛上皮の及をるつて全面が被わ扎ることはない，こ机ら 三種の被㠅上皮山どの上うに配置されているかをみる と,

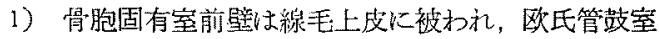
入口部に近づけば股子状上皮となり屚平上皮に臬 る.

2）骨胞固有室後壁においては攱膜より内耳室側壁に

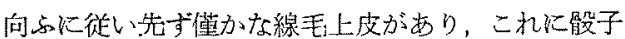
状上皮が続き，遂に内皮緗胞樴上文に移行する。

3）鼓室上窝，内耳鼓室側壁，聴小骨及び鼓膜室倒の 上皮は屚平上皮

4）欧氏管粘膜は総じ線毛上皮をもつて被㠅され，な 打杯状細胞の介在するのが見られる，しかし杯状細 胞は中耳粘膜においては一個といえども証明されな

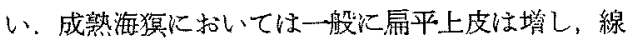
毛上皮は減少する。また海㺍豉室粘膜は部位により

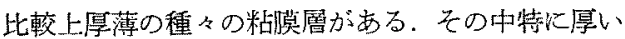
層は粘膜部位を挙げれば下記の如くである。

1）豉膜に近接する鼓室粘膜部

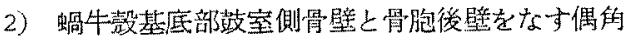
辺縁の粘膜

3）鼓室上简粘膜並びに桘骨々頭に附着する靶带辺 縁の粘膜

4）欧氏管豉室入口部附近の粘膜

ここに與味ある点は著者の動物実鈳に批いて感作した海 犋に変形菌を注入した增合の粘膜の肥厚状態である、特 に厚い粘膜部位 1）2）3）4）では土他の粘漠部位に比較 して著明に肥厚している，蝸牛款壁骨に按する粘膜は， 他の粘膜部位が著明他肥厚するにかかわらず比較的肥厚 状態は軽度である，即ち 1）2）3）4）の部位に打ける 粘膜は愿い状態であるが，フレルギ一反応及び細菌に刘 寸る感染に対しては比較的抵抗力が弱く強く反应する。

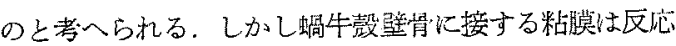
に薄い割合にアレルギー仪応に対し，又組菌に対する感 染他対しても抵抗力が強い上らに考入られる。これは一 般に分娩後日浅き海犋，鼓室粘膜殊に鼓室上裔粘膜は成

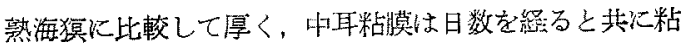
膜の厚さが減少し，成熟海猽に捣いては極めて薄層とな る. 生後日数少ない海猉つ粘脱は絬締織基留少く殆んど 造蟣維細胞，游走細胞，破骨細胞等の細胞性成分よりな り，且つ膠様組織が存在し粘膜が愿いが日数を程ると共 
に漸㳄結締織性の基質が增加してき，逆に細胞性構成分 子及び膠様組織の消失等により粘膜層は薄くなる，次第 に粘膜の中央部滥管網の発澾著明となり，粘膜の厚い、 のは血管絧の発達が負ふところが大である。

この線毛上皮の部位の粘嗼と㴊平上皮下の粘膛組織は 最も薄い層で，骰子状上皮下組織がこれに次ぎ厚さが殊 に影蕒な粘膜部は線毛上皮が破つている。

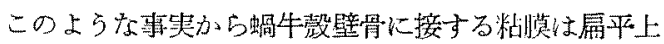
皮で破われ，他の線毛上皮の部位に比較して血管網の発 達がやや劣つており，且つ結締征基質も劣るものと見な される。この関係から線毛上皮の部位はアレルギー反応 及び細菌の感染に対して锐敏に反応するかと考へられ。 る.さて線毛上皮のフレルギー性に対する態度に就いて 述べると, 変形菌注入後 4 時間，24時間，3 日経過時に 特ける線毛上皮が所々剥離が認められるが，この事実を Proetz は Desquamation がフレルギーの時に早く起る と上皮細胞は膨化し，基䃉膜から脱落すると述べてい る，卵白を作用されると，先ず細胞体は縮少し，細肘顆 粒は增加するが，次いて細胞内に水泡の形成が起り，膨 化し原形質は澄明となり，細胞顆粒は核周に集合し長時 間後細胞は融合融解滛行する。文細胞内水泡の形成 が起ると，線毛性脱落し，原形質の透過性が高まり基礎

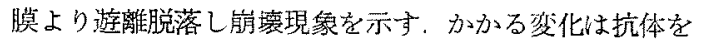
含さ細胞に抗原が波及して起る正常のアレルギー反応で ある、線毛の脱落に就いては，線毛細別に扣けるアレル ギー現象即ち卵白アルブミン刺軲に対する線毛の態度で であるが，線毛畑白アルブミンで刺钱を加えるとしば らくして線毛運程は停止し，細胞は収縮，短時間後に原 形質は澄明となり線毛の形，排到が乱れ一部脱落するよ らになる，次いて細胞内には水泡の形成が起り，線毛は 細胞体より次々と分離して行き，脚化現象を是する。 又 アレルギー性中耳炎に関する実験的研究において国見は 卵白アルブミンで感作した結果, 線毛は多くは配列が乱 れ，消失するものが多いと述べている，著者の実䮖に括 Wても変形菌 (P.V.) 注入後比較的早期紹過では線毛 の脱落が認められる。以上述べた線毛上皮の分速穴進, 膨化及び線毛脱落小細菌性炎症にて子当然考入られる事

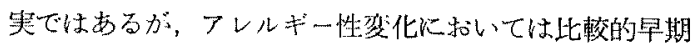
に出晲し，且つ箱菌性炎症に比較して著明に表はれる と著者は考へる。白川 ${ }^{36)}$ はアレルギ一の立場から観た

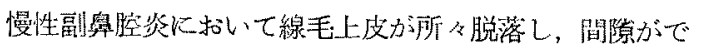

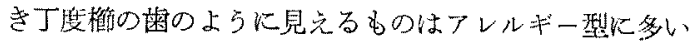
と述べている，固城の棒駼においても上皮細胞の一部认
剥離崩解し，一部は空胞化をきたしたと述べている。こ こで線毛の脱落消失に就いて問題になる点は技術的操作 である、線毛はアルカリには割合強く，酸には謌いとさ れているが骨脱灰の際 10\% の蛲酸を約 2 週間使用する が，これが線毛に対してどのように悪影響を与克るかで ある、しかし著者の実験恃総て生体固定を行い脱灰の際 には充分にホルマリンで固定されているため，焬酸が作 用してもなんら悪影響を蒙ることはなく，線毛脱落快空 胞化の著奛な部位において多く見られる。これらの2点 から線毛の脱落は技術的操作の影響が薄く、アレルギー 変化によるものと判定される. 線毛上皮の剶離の問題で も技術的操作が上げられるが，次の三点から

1) 生体固体を施行した事

2）粘膜下組織に括けるアレルギー性変化の著明な事

3）対照と比較した事

動物を感作することなく，変形菌（P.V）のみ注入した 場合には注入後 4 時間，24時間に和いては中耳粘膜に 著时な変化は認められず潘活正常近く注入後 3 日緼過 した際の所見が感作した海独に变形菌（P.V） 注入し て4時間経過した際つ粘膜所見とほぼ一致する.以上の 事奏より線毛上皮の剝離がアレルギー性反応に上るもの と云える、ごれで中耳腔に賗溜する分泌物の状態及び推 移に就いて述べてみるに，变型菌 (P.V) 注入後 4 時間， 24 時間の比較的早期に招いては線維素性物質の折出, 赤血球及び少数の円形細胞を認める. その中に混在して 好酸球が証明できる. 3 日経過すると逆に円形細胞特に 好中球が次第に多くなり，線維索性物質及び赤血球が少 なくなり，好酸球の数はとれにとるなつてすくなくなつ

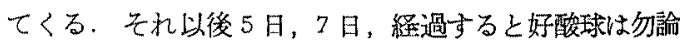
のこと線維素性物質及び赤血球の折出怯洼とえと認めら れず，それと反対に好中球を主体とした円形細胞が多数 認められるようになる。即ち膿の䝪溜である，10日経 渦士ると，次第に膿の貯溜量も減少し，15日，30日経 過すれば中耳悾には分泌物は認められなくなる。対昭側 に括ける中耳腔の 分泌物状態は 4 時間， 24 時間経過汇 怙いて極僅少の線維素性物質と赤血球を認めるが，好中 球㥜圽られない，しかしそれ以後 3 日，5日，7日， 10 日，15日，30日の各経過時に批いては中耳腔に分速 物は認められない。

以上の如く中耳腔に打汗る分汹物貯溜状態及び推移变

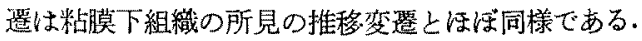

次に粘膜下組織に就いて教察を加党て友るに変形菌 (P.V) 注入後 4 時間， 24 時間経過し粘漠下組織所見で 
は著明な変化は浮遁，出血巣，好酸球の出現が特徽的で ある、これ等の著明な浮膘及び出血菓多数の好酸球の出 現は初期のアレルギー性変化に批ける Trias と云つて る過言でない，白川及び固城はフレルギー反応における 粘莫下繥織の重要な所見は浮腟，出血巣の著明な出現， 好酸球の浸潤であると報告している. Hansel は牛乳， 馬血清で感作した動物実験で粘膜下䋎織の各所以出血樂 々著明な浮陻及び多数の好酸球の出現を認めこれ等の所 見はアレルギー性特有の病変であると述べている，

Koch る同様な動物实駼を行い短い、時間に扣いては粘 膜下緣絨浮脜，多数の出血，好酸球の出現を示したと 述ベこれ等の縕繕所見はフレルギー情病変の際に愿々認 められると記載している。３日絹過すると著时な出血单

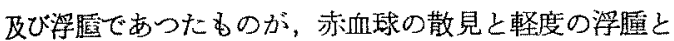
変ってくる.しかる相当数認められた好酸球は少数に变 つてくる. Hansel は実験の結果フレルギーの変化は比 僌的早期においては著明汇表われ 48 時間を境として下 降線をだどり1週間にて次第に病变怯恢復に向うと述心゙ 固城も同様に病変は発病後 2 3 日で最高に達し1週間 持続し恢復に向うと記載し，Koch 数日後においては

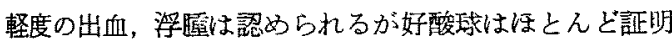
できなからたとし，2ケ月半恕過した場合の粘漠下組織 は厚くなつた線維化を示したと報告している，藷者の奏

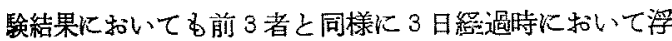
㙕，出血，好酸球の出現は次第に俥減し，即ちアレルギ 一性特有の病変はすでに下降線をたどつている。こ机等 の事実は感作された状態の所に紐菌が浸入し，そのため 3 日絽過期江到り細菌の活動が活淡となり細菌性の病变 が第第に強くなり，フレルギー性抦変が弱くなつてきた 結果であると判断される．5日以後10日䌡過において

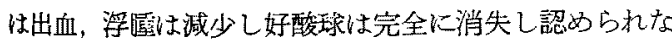
くなる，それに反し結合組織の增殖，毛細血管の脑張增

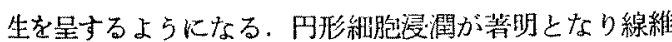
芽細胞及び骨周辺に骨茅細咆の出現がみられこれ等の組 䋘所見は日数の絽過化従つて增強し，7日，10日に到れ ば骨新生像一部に括いては肉芽の発生を認め，15日か ら 30 日経過する之線維芽細胞及び，骨芽細胞は認められ るが他の所見は次第に減少してくる．しかし硝子様化が

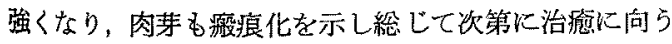
ものである.

次ぎ対照側に和ける粘膜下組織の所見は，4時間及 び 24 時間絽過時に扎いては浮遥，出血好酸球の出現を 諰めるが感作した後に変形菌（P.V）を注入した場合の

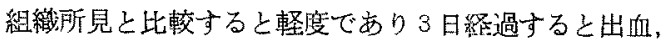
好酸球は認められで，軽度の浮遁のみが認められ硝子化 を呈し，粘獏恃眯億状を示す，5日に到机ば感作耳にお

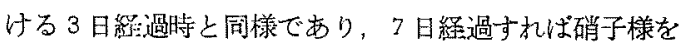
示し10日，15日，30日の各経過時に捺いては7 日経過 時比括ける所見々ほぼ同様で治癒つ状態を示す，以上述 べた如く中耳临に批ける分泌物の貯溜状態及び性状は時 間的絽過上共沉変化し同時汇粘膜の所見も推移变要索示 す.さて前に述べた如きアレルギー性病変に伴ら浮尰， 好酸球の出物に就いて考光てみる。好酸球が組織中增 加出現することと丁レルギーとの閶绿は古くから注目さ れていた事笑である、臨床的には気管支喘息，蒙麻渗湿 达等のアレルギー疾患に際して好酸球增多の見られるこ

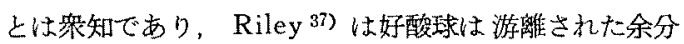
の組織ヒスタミンの破雴及び運搬の青任を持つていると 述へ，好酸球增多は抗原殊に異種蛋白に対寸る不可欠的 な細胞要素であり，且つ1つの特微であると看做されて いる．Derlacki 38) はアレルギー性中耳炎の症状例に拈 いて好酸球の出現を記载し，分泌物や組織に增加した好 酸球の所見はフレルギー性反応注対する仮定的な証拋で あると述べてある，Jonesは䫀聑性アレルギーを原因と したアレルギ一性中耳炎の1例を報告しその汬液性分泌 物中に多数の好酸球が証明され且つ組織中にあ多数の好 酸球を見出したと述べている．Koch は慢性中耳炎の

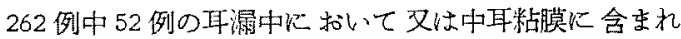

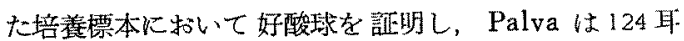
の標本において48例炕好酸球を発見したと述べている. Senteuria ${ }^{39)}$ は耳の分议物 75 例に対して 10 例に括い て好配球を発見し，Sueks ${ }^{40)}$ は強力なアレルギーの菜 地を持つた 50 例に打いて 好酸球を発見したと述べてい る.以上述べた如くアレルギーと好酸球の出現とは密接 なる関係にあり，Hansel, Derlacki 等はアレルギー性 の場合には分汹物中の好酸球䘮重視して抢り Koch は アレルギー性であるか，否かは eosinophilie であるが Aneosiuophilie であるかによつて区別できると云つて いる. 分泌物中の好酸球がアレルギー性と非アレルギー 性の鑑別にどの程度の意我を有するがなな拓今後の問題

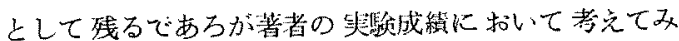
るに非アレルギー幽の場合には殆んど証明できないのに 詨しアレルギー性病変の際には此皎的早期に分泌物中あ るいは粘慕下組織に好酸球が琶められることからこの好 酸球の出現は重要な意義があるここが知られる，次は好 酸球の出現数の閆題であるが，炎症即ち細菌性炎症に和 
いても時には軽度の好酸球の出現をみる. しかしこの好 酸球の数はフレルギー性病変に扣ける好酸球の数之比較 してみるとそこには著しい差を認める。Palva 41) は

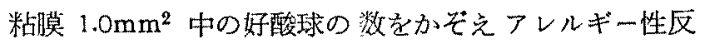
肌によるものであ机ば4〜5個以上の出現を見ると述べ， 国見は動物実駼に括いて好酸球の出現は非アレルギーの 場合には殆えど虫められないがアレルギー性の場合には 相当数䖵められると迹べた. 次に浮遁に就いて考へてみ

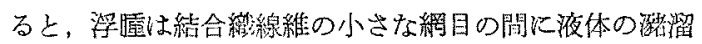
している状態である。これはへマトキリン，エオギン染 色では透明見兄着色しない. Hansel は正常組織で浮

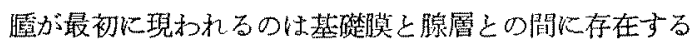
之毛細血管絧の層に表わ軽度は殆んどこのところに限 局し，浮德状肥大やポリーブはこの部の㾞脹の結果であ ると述べた。

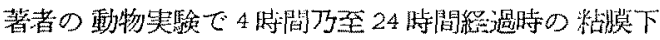
悢織に抢ける浮蒝の状態は毛細血管絧の層に限局したも のではなく，全層に亘つて著明に出現している．かかる 浮檻の成因はアレルギー反応によつて起る stasis 並び に助管透過性の㠵進によることは勿論のこと一部には Eggston and Voeff 42) の云ふ線雜性静脈周囲资や淋巴 管周囲炎の結果静脈や淋肥管の閉塞をきたして浮婳や随 脹が起る，炎症性浮遮では同時に周囲には著时な円形細 胞特に多核白血球の浸潤が認められるが，アレルギー性 浮遮では円形細胞浸潤は軽度で時には全然これが認めら れない，同時にみられる萻明な出血巣及び好酸球の出現 はアレルギー性浮䐦を決定づける．以上の病理絽織学的 所見から著者住次の如き二点を考察することができる.

第一は感作した海犋の中耳堎に变形菌 (P.V) を注入 した際の中耳粘膜の治癋迄にいたる族理組織学的所見の 㤎遷は,

a) アレルギー性满変を示守特期

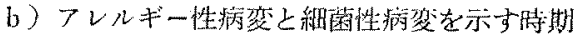

c）細菌性病変考示与㭙期

d) 治癒時期

の4つに区別できる.

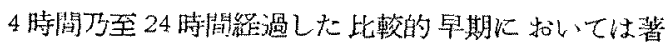

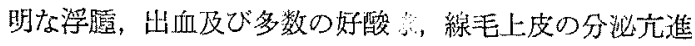
及び粘膜上皮の杯細胞形成，即らアレルギー性病変特有 の所見を示し，次に 3 日絿過した時期に到れば，次第に 結合織增殖，円形細胞の出現がみられ毛細血管の拉張を 呈し即ち細菌性病変の所見を呈するようになる。一方に 拁いては著明な出血栄，浮䢚は次第に軽減し赤血球の散
見, 轾度の浮烥に変り, 且つ好酸球の出現数す減少し， 非定型的なアレルギー性病变の混合型の時期である，7 日から10日経過するとアレルギー性病变特有な各々の

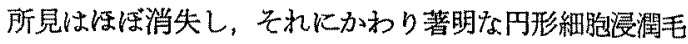
細血管の脑張增生，線䧽芽細胞の出現，骨の新生像が認 められるようになり純然たる 細菌性病变が出現してく る. 即ち 細菌性病变の時期で五る。次飞 15 日から 30

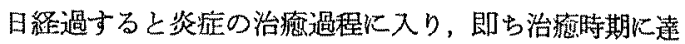
する、アレルギー性組織反纫はすず血管壁の变化，循㻴 障碍をあつて表われると云はれているが，これからすれ ばアレルギー性病変の時期をあいい怡血管循環障碍又は 非炎症性の時期之云つてるよいか子知れない，Hansel は慢性副鼻腔炎を1）アレルギー型，2）化膿型，3） 温合型に分類し，アレルギー型はアレルギー組織反応に よつて起るもので浮䐺と好酸球浸㵎を主とした変化であ り，化膿型は細菌感染によつて起り，混合型はフレルキ 一性病変沺細菌感染が 起つたるのであるとしている. 萻苦が 述べたのは中耳粘膜の病的变化の 推移であり， Hansel の述べたのは上頼洞粘膜の病的分類であり，同 一視することは間題であるが，雨者間炕共通した点があ る上らに考えられる．臨床沈㧍いて屚々経験するレルギ 一性中耳炎と㨋者の動物实験で得られた結果を総合し考 えてみると，

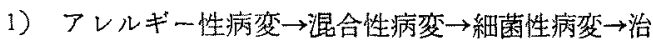
瘾期 $\rightarrow$ 完全治癐

2）アレルギー性病変 $\rightarrow$ 混合性病変 $\rightarrow$ 細菌性病変 $\rightarrow$ 治

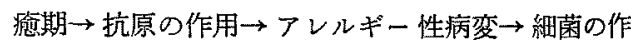
用 $\rightarrow$ 細菌性病变 $\rightarrow$ 治㾍期

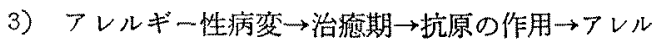
ギー性病変（細菌が作用せず純然たるアレルギー性 病変)

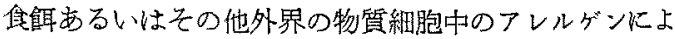
つて生体ですでに感作され過敏な状態㔀ちアレルギーの 状態になつておりそこに同種のアレルゲンが耳管経由， 中耳腔に浸入することによりアレルギー性病变を港起す

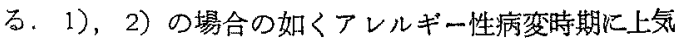
道の症患江伴ひ細菌が耳管経由, 中耳悾に浸入し循環的 に各病変時期を経過する．又コレルギー性病変時期より 混合性病変及び細菌性病変の各時期を絽過することなく 直接治畄時期に移行しつつある時，再び同種のフレルゲ ンが浸入しアレルギー性病变にもどり完全治療に到らな い. 即ち 3) の場合である.

论に変形菌 (P.V) のみ注入した場合と感作された海 
慎に变形菌 (P.V) 家注入した場合の中耳粘莫を比較検 討してみると，前に述へだ如く感作された海獏て变形菌 を注入した場合の 4 時閌乃至 24 時間絽過時に括ける中 耳粘膜は著明な浮㯖，出血及び好酸球の出現を呈するが， 変形菌 (P.V)のみ注入した場合には，4 時間及び 24 時 間経逼時までほとんど中耳粘膛に変化が認められない。 しかし3日程過すると中耳粘膜に好中玟浸潤が見られる ようになり，両者間にすでに 3 日の差が生じている。 又 治觉状態を呈する时期は変形菌 (P.V) のみ注入した場 合の方が早い，即ち感作された海猪に变形菌を注入した 場合の方が病変の絽過が長く变形菌 (P.V) のみ注入し た場合の病変は短い経過をとる。これは感作された状態 即らアレルギー珄素因を有する状態に括いては細菌が此 較的浸入しやすく又浸入した細菌の作用がより強いもの と考光られる.Gutman A ${ }^{43)}$ は感作された粘膜は正常 战莫に比較して細菌に対する反応が全く異なると云つて 抢り，国見はアレルギー性素因を有するるのは組菌性中 耳炎の発現に大なる影響を与兄，細菌の毒素作用を強め るのではないかと云つて抢り，Dohlmann ${ }^{44)}$ は感作さ れた絬膜に細菌感染が起つた場合には通常の夫れと比較 して全く異なる反応を呈すると指摘している，著者の実 駼においてこれ等の諸説をうらづける成縝が得られた。

次に内耳組織特に血管帯, ニルチ氏器細胞, ライスネ 儿氏膜及び前庭階，鼓室階の状態汇就いて考察を加えて みる、血管帯の拡張は30日絽過を除いては程度の差は あるが大部分に認められる、4 時間縃過の比較的早い、時

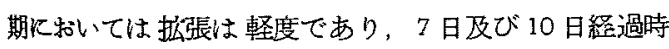
で血管带の泓張はやや著明となり，15日絽過すると 㹡張は次第に絟減し始め30日に達すれではぼ正常にも ぞる、空胞化は 4 時間経過では認められないが，24诗 間以後の経過では空胞化を示す。

次にコルチ氏の各細胞は全経過において膨化を示す が、ダイテル氏細胞とへンゼン氏細胞は同程度に膨化を 示すが，クラヂウス氏細胞は前二者に比較してやや劣 る、又内外毛細脆は一般に原形がくづれ。不明瞭なるの が多い，各細胞の境界は明膫なるのもあり，不明膫なる のも存在し一定ではない，ライスネル氏膜の状態就い ては正常状態な至は臌隆状態のものが多いが，少数に括 いては弛緩を呈す. 前庭階及び鼓室階に線維䒺性物質の 折出，円形細胞の游出，あるい恃赤血球の浮出を! 部の ものに怙いて認められる. 対照側に就いては血管帯の搪 張コルチ氏器細胞の膨化及びライスネル氏膜の恋化を認 めるか，注入側比此較してその变化は少ない，前庭階及
び鼓室階はほとんど変化は認められない，

血管带の变化に就いては仲村が聴器結核アレルギーの 実験において上皮細胞の堙大，血管带の摭張，空胞化等

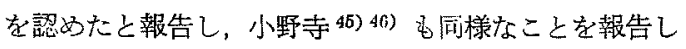

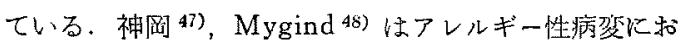
ける迷路組織变化の際，血管带の変化を重視し 全例の 80\%に高度の病変を認め極端な例に批いては上皮が破壊 し，激しい出血を見たと記載している，即ち内耳血管は 所謂終末動脈であると云われ，殊飞その未端である血管

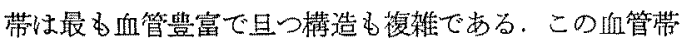
は内リンパ腔に直接倿しているため, 該部の病変, 殊 にアレルギー性えの影響に対しては非常に敏感であると

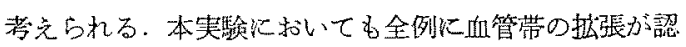
められ旦つ早期から出現している．かよらにアレルギー 性反応は血管带において最も早期に表和れる，一方血管 帯の変化はこの部分が異物に対して抵抗が弱く，Rössle Opie ${ }^{49)}$ ，茂貫 ${ }^{60)}$ ，Menkin ${ }^{51)}$ 等の謂ふ病栄部の抗原

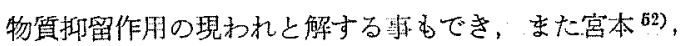
河本 38 ) 異物阻止作朋の現われと解する事もできる.7 日及び 10 日絽過すると再び㹡張が唉くなり，且つ充血

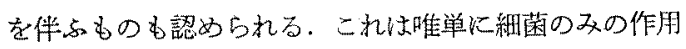

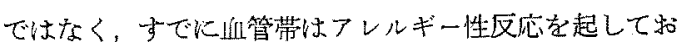
り，そこに細菌が浸入し，細菌自身の毒素力が增しこ の毒素力が刺激となり再びアレルギー性反応が強まる。 即ちアレルギー性反応と細菌毒䯃力との閴に相互協調作 用が成立し強く血管带に作用するためと想像する。

コルヂ氏器に就いて述べてみるに,コルチ氏器は内耳 機構の中核であり，その病変湓的て重要な意味を有す

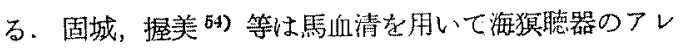
ルギー性変化を観察し、ュルチ氏器科胞の膨化, 䐟脹 し，胞体融合の傾向があり，特に上方迴転に著明であ り，病変高度の場合には，ヘンゼン，ダイテル及びクラ

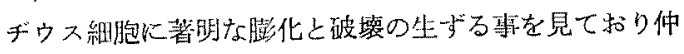

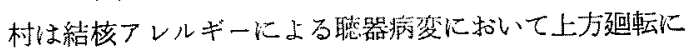
执いてはやや篓縮の像を呈すると述べておる，Rössle 56) はアレルギー反応による内耳組織の変化の中コルチ 氏器細胞はアレルギー変化に対して比較的早〈反応し， 特にヘンゼン氏細胞ダイテル氏細臨は反応に敏感であり 膨化の像を示す，滲出液が各細胞間に貯溜し細胞間の 境界は不明瞭となる。このような変化は3日を頂点にし

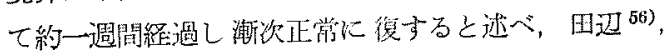
Schwartzmann ${ }^{5 i)}$ は海椇にアルチユス及びシユ型組織 反応を惹起させたが，コルチ氏器の変化炕就いては，動 
物個々の抗原に対する感受性の差によつて，夫ヶの支持 細胞の侵され方に軽重があると述べ，倉并，追川58， 八木沢 ${ }^{593}$ は同様にコルチ氏器の変化は膨大像, 破壊像 または荽縮像等がみられ，反応注射後の時間によつてを の型と程度を異にしておらり，細胞間の藽界はやや不朋膫 である之記载している，著者の実験例に执いてもコルチ

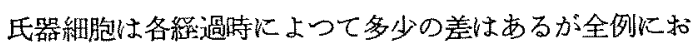
いて膨化し，その細胞膨化の程度は和田 Williams ${ }^{60)}$ の 述べている如くダイテル氏細肘，ヘンゼン氏細胞，クラ ウヂウス氏細胞の順に膨化が強い，細胞間に線維素性物 質が折出し境界の不朋瞙を是する例も認められる. No. 60, No. 83 Kおいて好酸球を証明できたことは與味ある 事実である. 即ちコルチ氏器細胞の膨化も血管带の变化 と同侎にアレルギー反応に対し鋭敏に作用し，且つアレ ルギ一反応の強弱に深い関係を持ち，又細脂毒素力の強 化作用にも滐く関係を持つ上うに想像される，中耳粘膜 のフレルギー性病变の絴過は短く 3 日前後を頂点とし， 漸次下隆し約一週間後には消退してしまうが，これは内 耳が解剖学的位置的関係から時間的に病変の差が起るこ と当然の事柄である.

次にライスネル氏償に就いて，その状態を举上即ち内 淋巴办薑を示するのと，沈下 (弛緩) 即ち内耳虚脱を示 寸ものに分けると，著者の実験においては，正常状態， 次いで举上（膨隆）の順に多く，沈下例は少くない，宿 間の実験においても同様に正常状態及び举上が多く，沈 下が少くない，伊達61はライスネル氏膜の弛緩が多い上 うであると述べ，神岡はライスネル氏膜の顕著な挙上を 家兔の㯖器シュワルッマン型組穖反応で説明している.

最後に前庭階に和ける線維素物質の折出状態士比較 的早期な時期と 15 日及び 30 日経過飞於いては認められ ず，3 日及び 5 日絽過では線維素性物質の折出が少量認 められ7日及び 10 日経過では線維素物質の折出はやや 著明となつてくる.この経過に抋いてもアレルギー反応 と細菌との間に深い関保があり7日及び10日経過した 時期に線維素性物質の折出がやや著明となるのは，これ はすでに内耳組織がフレルギー素因を有するために細菌 が漫入しやすく旦つ細菌の畕菜力作用が強くなるためと 考へられる。つまりアレルギー素因と云ふ状態が内耳組 織の変化にも大きな役割をしている.

以上血管带, コルチ氏器細胞の変化, ライスネル氏膜 の状態，線維素性物質の折出等述べてきたが，この中コ ルチ氏器細胞の变化及びライスホル氏膜の状態就いて は充分に注意する必要がある，この理由は1）生体固体
の問題，2）死後变化の問題，3）脱灰時における問題, 4)切片作製に括ける挍術の問題等を取り上け゚なくては ならない, Lang 62), Wolff ${ }^{63)}$, Mayer ${ }^{64)}$ はライスネル 氏獏及びュルチ氏器の刷立性変化はこれを病的と解すべ きでなく，Brühl 65) は聴器は死直後にかあるいは短時 間内に固定せられ且つ従来行はれておるよりも，更に精 密なる方法で検索する事が可能でない限りライスネル氏 膜の状態、コルチ哭の状態をもつて直ちに病的と判定

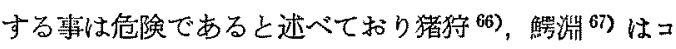
ルチ氏器, ライスネル氏膜に見られる变化は死後䋨過せ る時間に必ずしも平行せず，且つ死後同一時間を経過せ るものに括いてる，必ずしも一致せる所見を呈すること なく, 専ら固定液の流通の良否即ち聴器固定に上り種々 異なる所見を示す. Wittmaack ${ }^{68)}$, 及び久保 ${ }^{69)}$, 田所, 渡辺 ${ }^{60)}$ は固定がかなり良好なる際はコルチ氏器の各細 胞は僅か、濁泪するのみで膨大の傾向を示し，時には膨 大弛緩して内容の湓出せる所見を示し，固定が不完全に なるに従つて、コルチ氏器に硝子化及び扁平化の傾向を 示すと述へてている，また実験の季節即ち夏の場合，冬の 場合によつて内耳所見の差を認めたと云つている、この 上らに標本作製途上の諸障碍が合一して，全く子期し得 ぬ事柄があるに溜意し，標本を観察するように充分に注 意を払ふ必要がある．以上中耳アレルギーの寒験に批、 て見られた内耳病変は中耳フレルギーのために起る全身 アレルギーの分症として内耳に臟器撰択が行われたとみ なすべきか，局所アレルギーが中耳に起りその病変が練 菌感染による中耳炎の場合と同じように唯内耳波及し たものと考えるべきが非常にむづかしい䦓題であり，今 後の課題である.

\section{第 8 章 結語}

1）成熟海猽を卵白アルブミンで感作しその感作た状 態の海冝に变形菌 (P.V) を注入し中耳粘膜の 組穖学的 所見を時間的経過を追つて観察した.

2) 4 時間乃至 24 時間繰過時即万注入後比輘的早期 飞おける粘莫の所見は線毛上皮では粘膜上皮の分泌充 進，膨化形成線毛脱落消失する．粘膜下組織にむいては 著明な浮缠，出血索認め多数の好酸球を証明できる. 3 日経過においては浮藏，出血はやや軽減し少数の好配球 を認めるが同時に結合組織が殖增し，円形細䶼浸潤の出 現を示す，5 日経過に颃いては上皮の一部の扁平化战膜 下組織では毛絀血管の扰張及び增生，円形細胞漫潤が著 明になり，他にりンパ管がやや哆開し骨芽細胞が認めら れ骨の 新生像を示す。15 日絽過時期においては線毛上 
皮の排列は正しく線毛は存在する，粘膜下組織に和いて は毛細血管の昖張浮霹は洼とんど認められ，硝子化がみ

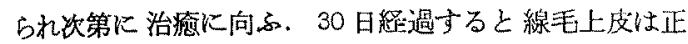
常に復し粘莫下組織炕括いては炎症の治湓過程を示す。

3）以上の粘膜の变化からアレルギー性病変, 混合性 病変, 細菌性病変, 治癒時期に区分できる。4時間乃至 24 時間経過時期をつレルギ一性病変时期とし，3日程過 湿合性病变時期，5 日，7 日，10日絽過時期を細菌性 病変時期 15 日及び 30 日總過を治瘾時期とする.

4）フレルギー性素因を有する粘膜には細菌が浸入乙 やすく，且つ浸入した紐菌は先の毒素力の作用が增す。

5）同時に内耳組織特に血管帯, コルチ氏器, ライス ネル氏膜前庭階及び嬂室階の变化を時間的縃過を追つて 観察した。

6）血管带は程度の差はあるが全例に心いて拡張が認 められ，空胞化を呈す、しかし15 日及び30 日檤過時期 に括いて橉次恢復する傾向を示す、コルチ氏器細胞るダ イテル氏，ヘンビン氏，クラヂウス氏各細胞順に膨化を 示す. 各細胞間の境界は明膫なもの不明膫なるものが認 められ，また線維索性物質の折出を認める.ライスネル 氏膜は正常状態が多く次いて膨隆弛緩状態を示す，前㛹 階には線維素性物質の折出を3日，5日，10日経過時期 に認められる。

7）内耳組織の变化のうちライスネル氏膜の状態及び コルチ氏器細胞の変化は生体固定，瀻酸の長持間の使用，

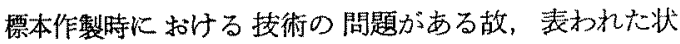
態をもつて直ちに病的と判断することは非常伦危険であ る. 生体死後変化を充分に頭にいれておく必要がある。

\section{鋯考文献}

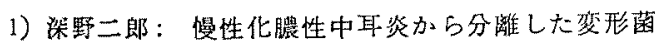
Kいて，日耳鼻，60：196，1957。(昭32)。 2) Pirqu$e t$, : 3) より (Die Serum Krankheit). 3) Riechet, T.: Der Ausdruck Anaphylaxie. Handbuch der Allg Pathologie., $1924 . \quad$ 4) Rössle, R.: Die Geweblich Veränderungen nach Serum injektion. Wien, Klin, Wschr., 24; 161, 1932. 5) Arthus, G.: 4) より. 6) Neil, J.M.: An "immediate" skin reaction which can be passively transfered. J. Exp., Med., 49；35，1934，7）三田定則；血清学

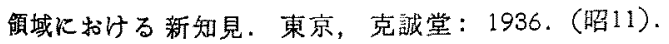

8) Urbach, E:: Klinik und Therapie der Allergischen Erkrankungen. Klin., Med. 31; 440, 1949.

9）糤方富堆：Arthus 現象を規定する因子の研究. 血
清色疫学蓶誌，2；453．1937. (昭16). 10) 武田睠 男：アレルギー性劦化の病理学。アレルギー時報，6; 215, 1951（昭26). 11) Lewis, E.R.: Otitis media and Allergy. Ann. Otol. Rhin. \& Laryng., 38; 185, 1929. 12) Proetz, A.W.: Allergy in the ear and the internal ear. Ann. Otol. Rhin. \& Laryng., 40; 52, 1932. 13) Jones, M.F.: Alleriy otitis media Ann. Otol. Rhin \& Laryng., 49; 910, 1938. 14）山㱦春三：筫のアレルギーとフレルギー性につい

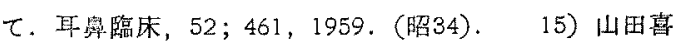
郎：アレルギー性中耳炎、猃断之治療，30；3，1946。 (昭21). 16) Hansel, F.K.: Pathological change of the tympanic membrane of guinea pig. (Serum Injektion.) Clinical Allergy (Mosby, St. Louis)., 542, 1953. 17) Koch, H.J.: Allergical Investigations of Chronic Otitis. Acta. Otolaryng. Suppl,

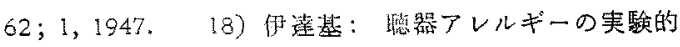
研究。日耳出，47；1768，1944（昭19）. 19）固城乘

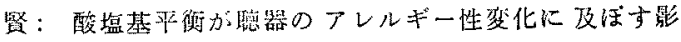

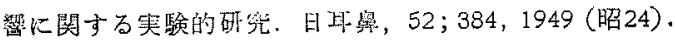
20）香宗我部明：低温の㯖器アレルギーに及ぼす影響

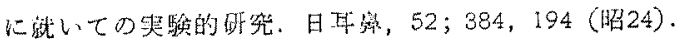
21) Derlacki, M.D.: Aural manifestation of allergy. Ann. Otol. Rhin. \& Laryng., 61 ; 179, 1952. 22）六島䅡一：慢性中䎲力タルの本態及び療法に就い

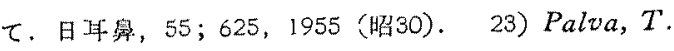
and Palva, A.: Allergic Changes in Mastoiditis Acta. Otolaryng., 56；215，1963. 24）国胃正明： アレルギー性中耳炎に関する实鮯的研究：日耳率，61； $744 ， 1958$ (昭33). 25) 中村信夫：結校アレルギー

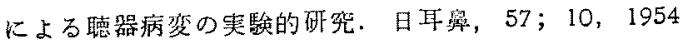
(昭29). 26) Meerhoff, W. and Meerhoff, A:

Die tuberculoese Infektion in der Pathologie des Innenohres. Laryngoscope., 62; 215, 1940. 27) 和

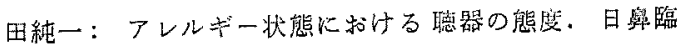
床, $52 ； 678,1962$. (昭37). 28) 量田厚二：アレル

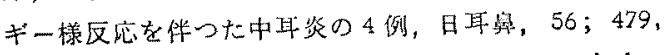
1956. (昭31). 29) Friedmann, I.: The Pathology of Secretory Media. Proc. Roy. Med., 56; 695, 1963.30) 白川吾一郎：フレルギー性内耳资に関す

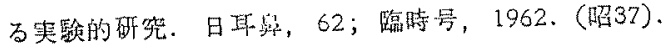

31）倉井寬子：追䟢法による琇器迷路アレルギーの実 影的研究。日耳鼻，62；2329，1962.（昭37）。32）日 


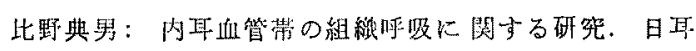
非, 58; 569，1955. (昭30). 33) 本杉雅英：中耳感

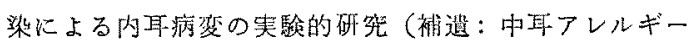

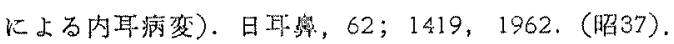
34）陷間啓芳：局所了レルギ一区地による末梢血行障

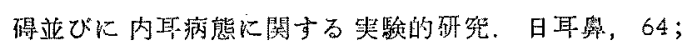
690, 1964. (昭39). 35) Koch, H.J.: 17) 上り.

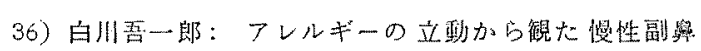

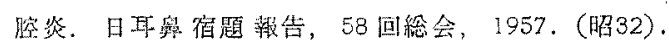
37) Riey, J.F.: The mastoid cells. Livingstone, Edinburgh-London, $1959 . \quad$ 38) Derlacki, M.D.: The Middle Ear, Symposium on the Allergy of the Ear. Trans. Amer. Acad. Ophthal. Otolaryng., 61; 91, 1951. 39) Senteuria, B.H.; Middle ear Eflusions; Causes and Treatment. Trans. Amer. Acad. Ophtal. Otolaryng., 64; 60, 1960. Sueks O.W.: Secretory Otitis Media. Laryngoscope., 59; 1002, $1949 . \quad$ 41) Palva T, and Palva A: Allergie Cange in the Mucosa of the Chronical Otitis Media. Ann. Otol. Rhin. \& Laryng. (Basal)., 24; 1, 1942. 42) Eggstion, A.A. and Wolff, D.: Histopathologyof the Ear, Nose and Throat Baltimore, the Willi ms and Wilkis Company., 639, 1947. 43) Gutman, aA.: Advances in Protein. Int. Chemist., 4; 156, $1941 . \quad$ 44) Dohlman, G.:

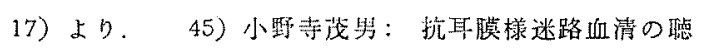

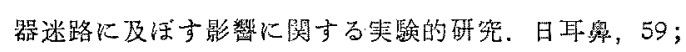
$1103 ， 1956$ (昭29). 46) 小野等茂咕：内耳アレル

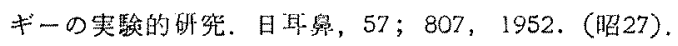

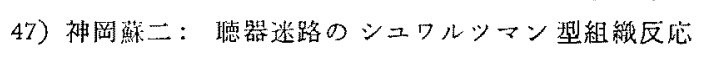

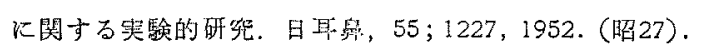
48) Mygind, S.M.: Experimental histological studies on the labyrinth. Acta. Otolaryng., 33; 75, 1945. 49) Opie, E,L. u Rössle, R.: Inflammation and immunity. J of Immunol., 17 ; 329, 1929. 50)

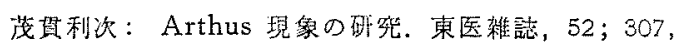
1938. (昭13). 51) Menkin, V.: Studies on inflammation V. The Mechanism of fixation by the inflammatory reaction. J. Exp. Med., 53; 171, 1931 .

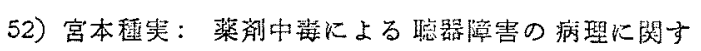

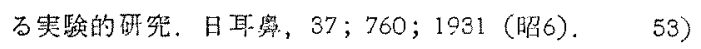

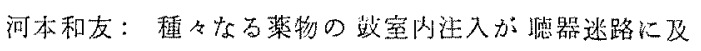

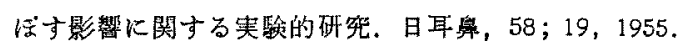

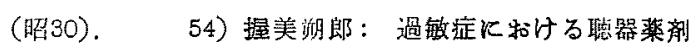
中齿の実駼的研究。日耳舞，56；246，1953(昭27). 55) Rössle, R.: Über die Merkmale der Entzundung im Allergische Organismus. Verh. d, Deutsch. Path. Geselsch, 17；281，1934. 56）田辺恬男:

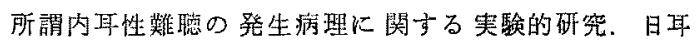
率, 56；721，1953. (搘27). 57) Schwartze, M.; Phenomenon of Lokal Tissue Reactivity. J. of Im-

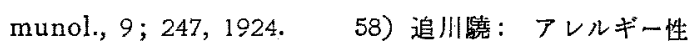

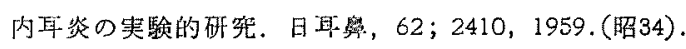
59)八木沢交吾：急性中耳炎に絖発女名迷路炎の病理.

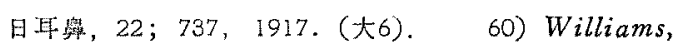
H.K.: Allergy of Inner Ear. Arch. Otolaryng,

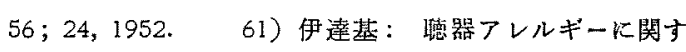
る笑就的矿究. 京府大, $43 ; 4,1948$. (昭23). Lange, W.: Beiträge zur pathologischen Anatomie der vom Mittelohr ausgehenden Labyrinthentzündungen. Passow. Beiträge. Bd., 1., 1; 1918.

Dean, L.W. \& Wolff, D.: Pathology and routes of infection in Labyrinthitis secondary to middle ear otitis. Ann. Otol. Rhin. \& Laryng., 43; 702, 1934. 64) Mayer, O.: Zur Entstenhung der sogenaten Labyrinthitis Serosa in Verlauf akuter Mittelohrentzündungen. Mschr. f. Ohr.-,Heilk und Laryng.-, Phin. 43; 60, 1929. 65) Brühl, T':

Experimentelle Studies zur Pathologie der akutentzündlichen Prozesse im Mittelohr (und im Labyrinth) Arch, f. Ohr.-, Nas.", u Kehl.-Heilk. Bd $90 ; 99,1926$. 66) 猪坊統一：家鬼聴器死後变化に 閶する笑験的啡究. 日卧率，55；491，1952. (昭27).

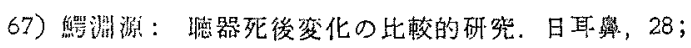
178, 1921. (大10). 68) Wittmacck, K.: Über artifiziell Postrmortale und agonale Beeinflussung der histologischen Befund in membranöse Labyrinth. Zschr. f. Hals.-, Nase.-, Ohrenheilis., 65; 157,

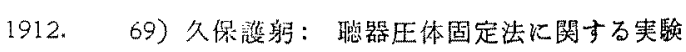
的研究。日耳無，27；1，1921。（大10)。70）田所喜

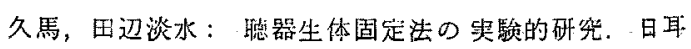
鼠, 27: 1, 1912. (大10).

（原稿到蓞=昭和 42.5 .24 日） 